\title{
Analysis of Product and Temperature of Biogas Combustion in Various Air Biogas Equivalence Ratio and Methane Content
}

\author{
Arini Wresta* and Aep Saepudin \\ Research Centre for Electrical Power and Mechatronics, Indonesian Institute of Sciences, \\ Kompleks LIPI Gd. 20, Jl. Sangkuriang, Bandung 40135, Indonesia
}

Received April 12, 2017; Accepted March 2, 2018

\begin{abstract}
Biogas resulted from anaerobic digestion of organic compounds have various methane content depend on the type of the degraded material. The methane content of biogas is range between $40-80 \%$ that influence the heating value and combustion characteristic of that biogas. The higher methane content can be obtained through upgrading biogas by removing $\mathrm{CO}_{2}$ and other trace components like $\mathrm{H}_{2} \mathrm{~S}, \mathrm{NH}_{3}$, and water vapor. This research was a simulation of product composition and temperature of biogas combustion in various methane content and air biogas equivalence ratio. Biogas combustion was done in combustion chamber at constant pressure of 1 atm. Biogas and air enter into combustion chamber at temperature approximately of $30{ }^{\circ} \mathrm{C}$ as the common ambient temperature in Indonesia. The input air was designed higher than stoichiometric need in order to reach complete combustion. Combustion reaction between methane and $\mathrm{O}_{2}$ then carried out in the combustion chamber to produce $\mathrm{CO}_{2}$ and $\mathrm{H}_{2} \mathrm{O}$. The product gases consisting of $\mathrm{CO}_{2}, \mathrm{H}_{2} \mathrm{O}, \mathrm{N}_{2}$, and excess $\mathrm{O}_{2}$, bring heat from combustion reaction and exit from combustion chamber at the higher temperature. The analysis was done for methane content range between 20 and $100 \%$ with air biogas equivalence ratio from 1 until 3. The simulation result showed that for $V \mathrm{~m}^{3}$ biogas, the combustion gases could reach 0.12271 until $1.26798 \mathrm{~V} \mathrm{gmol}$ with temperature above $700{ }^{\circ} \mathrm{C}$ until above $1900{ }^{\circ} \mathrm{C}$. More than $50 \%$ component in the combustion gases is $\mathrm{N}_{2}$ as inert material from input air to combustion chamber.
\end{abstract}

Keywords: product; temperature; biogas combustion; methane

\section{ABSTRAK}

Biogas yang dihasilkan dari peruraian berbagai macam senyawa organik memiliki kadar metana yang berbedabeda tergantung jenis senyawa organik yang diuraikan. Kadar metana dalam biogas bervariasi antara 40-80\%, sehingga mempengaruhi nilai panas dan karakteristik dari biogas tersebut. Kadar metana yang lebih tinggi dapat dicapai melalui pemurnian biogas dengan menghilangkan $\mathrm{CO}_{2}$ dan komponen-komponen kecil dalam biogas seperti $\mathrm{H}_{2} \mathrm{~S}, \mathrm{NH}_{3}$, dan uap air. Penelitian ini adalah simulasi terhadap komposisi produk dan suhu pembakaran biogas pada berbagai kadar metana dan perbandingan equivalen udara-biogas. Pembakaran biogas terjadi di ruang bakar pada tekanan konstan $1 \mathrm{~atm}$. Biogas dan udara memasuki ruang bakar pada temperatur $30{ }^{\circ} \mathrm{C}$, temperatur udara pada umumnya di Indonesia. Kuantitas udara pembakaran dirancang di atas kebutuhan stoikiometris untuk memperoleh pembakaran yang sempurna. Reaksi pembakaran kemudian terjadi di ruang bakar antara metana dan $\mathrm{O}_{2}$ menghasilkan $\mathrm{CO}_{2}$ dan $\mathrm{H}_{2} \mathrm{O}$. Gas hasil pembakaran mengandung $\mathrm{CO}_{2}, \mathrm{H}_{2} \mathrm{O}, \mathrm{N}_{2}$ inert, dan kelebihan $\mathrm{O}_{2}$, membawa panas yang dihasilkan dari reaksi pembakaran dan keluar dari ruang bakar dengan temperatur yang lebih tinggi. Analisis dilakukan pada kadar metana antara 20 dan 100\%, dan pada perbandingan equivalen udara-biogas antara 1 dan 3. Hasil simulasi menunjukkan bahwa untuk $V \mathrm{~m}^{3}$ biogas, jumlah gas hasil pembakaran dapat mencapai 0,12271 sampai $1,26798 \mathrm{~V} \mathrm{gmol} \mathrm{dengan} \mathrm{suhu} \mathrm{di} \mathrm{atas} 700{ }^{\circ} \mathrm{C}$ sampai di atas $1900{ }^{\circ} \mathrm{C}$. Lebih dari 50\% komponen di dalam gas hasil pembakaran adalah $\mathrm{N}_{2}$ sebagai gas inert yang terbawa bersama udara pembakaran.

Kata Kunci: produk; suhu; pembakaran biogas; metana

\section{INTRODUCTION}

The effort to save fossil fuels energy source in Indonesia is done continuously and seriously in some recent years through the development of research and application of renewable energy source, including biogas. The utilizations of cow manure as raw material for biogas production have been implemented in some small scale ranch, and the utilizations of human feces have been implemented in some area with concentrated population such as in boarding school, to produce biogas for electricity power generation. The

* Corresponding author.

DOI: $10.22146 / \mathrm{ijc} .23923$

Email address : awresta@gmail.com

Arini Wresta and Aep Saepudin 
others organic resources like sea weeds and organic waste like fruit and municipal solid waste also potentially to be used as raw material in biogas production. The capture of $\mathrm{CH}_{4}$ and $\mathrm{CO}_{2}$ emissions through anaerobic digestion of organic materials in biogas production is a simple and applicable process to solve the greenhouse effect and produce energy in the same time. The combustion process of biogas is also environmentally friendly because it produce more $\mathrm{H}_{2} \mathrm{O}$ than $\mathrm{CO}_{2}$ [1]. The heating value is significantly, can reach $20-26 \mathrm{MJ} / \mathrm{m}^{3}$ [2]. Compared with other source of renewable energy, biogas is considered as excellent [2] and environmentally friendly energy source, clean, and manageable [3].

Biogas resulted from anaerobic digestion of organic materials $[1,4]$ have various methane content depend on the type of raw material to be degraded and also the degradation condition in the digester, i.e. temperature and retention time [5]. The estimation of methane content from the degradation of protein is about $63 \%$ [6], from the degradation of fat is about $70 \%$ [6], and from the degradation of cellulose is about $50 \%$ [6]. The methane content of gas produced from sanitary landfill can reach $45-55 \%$ [7], or 45-65\% [8], lower than the methane content of biogas from anaerobic digestion process, caused by the possibility the present of air in semi-aerobic sanitary landfill degradation process, the aerobic process then dramatically decrease $\mathrm{CH}_{4}$ production [9] and methane content of biogas. Free- $\mathrm{H}_{2} \mathrm{~S}$ biogas can reach methane content more than $80 \%$ [10]. The higher methane content can be obtained through upgrading biogas by removing $\mathrm{CO}_{2}$ [1] and other trace component such as $\mathrm{H}_{2} \mathrm{~S}, \mathrm{NH}_{3}$, and water vapor. According to Karapidakis et al. [11], it possible to reach the methane content to nearly $100 \%$.

The variation of methane content in biogas will influence the heating value and combustion characteristics of that biogas. The temperature of combustion product gases is an important parameter to investigate the thermal phenomena in biogas combustion [3]. The temperature and composition of combustion product gases are also important parameters in equipment design of biogas system. Previous researches had studied the combustion characteristic of biogas, many researchers studied the combustion performance of biogas in internal combustion $\mathrm{SI}$ and $\mathrm{Cl}$ engine [8,12-20], the characteristics in microgas turbine [21-23] and also specifically on the characteristics in biogas burner [5,2430]. Largely, the previous researches of combustion in biogas burner were done in a certain methane content of biogas, i.e. $40 \%$ [29], 51\% [31], 60\% [5,27-29], 61\% [29$30]$, and also $100 \%$ [29]. The burners used were burner for gas turbine configuration [30], MILD or flameless burner [28], and lab scale furnace [27]. The thermal and chemical characteristics of conventional counter flow diffusion flame of biogas for methane content 100,60 , 61 and $40 \%$ have been studied [29]. Numerical study of oxygen dilution and temperature distribution of biogas combustion was studied by Noor et al. in MILD burner [28]. Dahiya et al. predict the composition and temperature of combustion product of biogas by considering the dissociation reaction of the product and component gases in the combustion process, and validated with experimental measurements [5]. For non-seeded biogas the study limited in the stoichiometric condition and for the product composition it was limited for methane content $60 \%$ and $\mathrm{CO}_{2} \quad 40 \%$ [5]. Caine present the theoretical temperature of biogas combustion using air as much as $100-200 \%$ of stoichiometric need, in various level of methane [26], however the methods to obtain the value of the temperatures were not explained and the product composition as a function of methane content and excess air was not presented. Considering that biogas from various type of substrate have various level of methane, the need of excess air to reach complete combustion, and besides the combustion temperature, the composition of combustion product gases is an important parameter in biogas equipment design, this research will analytically study the combustion characteristic of biogas through simulation of product and temperature that can be achieved in various level of methane from 20 to $100 \%$ and air biogas equivalence ratio from 1 to 3 . The combustion characteristics are investigated at constant pressure, and the results of the simulation are then compared with previous researches from literature.

\section{EXPERIMENTAL SECTION}

The system will be discussed in this study is biogas burner, the place where the combustion reaction between $\mathrm{CH}_{4}$ in the biogas and $\mathrm{O}_{2}$ from the air carried out. To determine the product composition and the temperature that can be achieved, it is needed to understand the scheme of the process and the combustion reaction that happen between biogas and air. In the simulation, the reaction is assumed as complete combustion, therefore, the products are $\mathrm{CO}_{2}$ and $\mathrm{H}_{2} \mathrm{O}$ only. There are also present others gases, i.e. $\mathrm{N}_{2}, \mathrm{CO}_{2}$ from biogas, and excess $\mathrm{O}_{2}$ that did not involve in the combustion reaction but present in the output gases stream from combustion chamber. In practice, those gases can be analyzed using gas analyzer or gas chromatography with certain detector. All of those gases are then called as combustion product gases, this gases bring heat that was produced from combustion reaction in the form of sensible heat and have higher temperature than the input gases stream. 


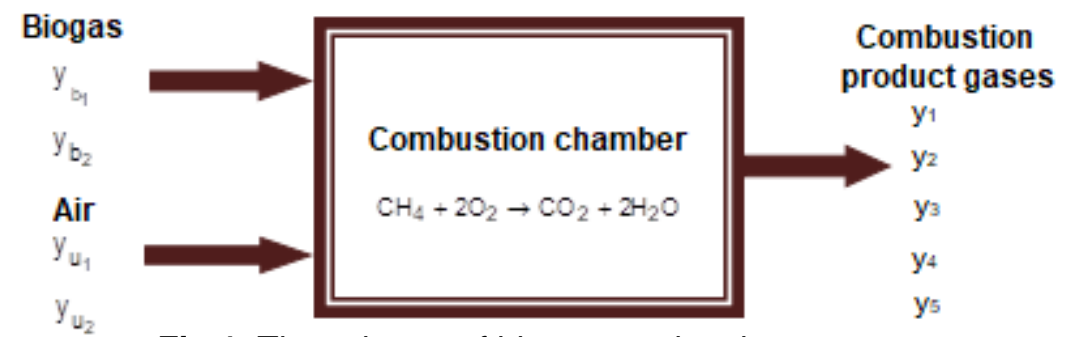

Fig 1. The scheme of biogas combustion process

\begin{tabular}{llllll}
\hline \multicolumn{5}{c}{$\mathrm{CH}_{4}+2 \mathrm{O}_{2} \rightarrow \mathrm{CO}_{2}+2 \mathrm{H}_{2} \mathrm{O}$} \\
\hline Feed & $\mathrm{CH}_{4}, \mathrm{gmol}$ & $\mathrm{O}_{2}, \mathrm{gmol}$ & $\mathrm{CO}_{2}, \mathrm{gmol}$ & $\mathrm{H}_{2} \mathrm{O}, \mathrm{gmol}$ & $\mathrm{N}_{2}, \mathrm{gmol}$ \\
\hline Reaction & $\mathrm{y}_{\mathrm{b}_{1}} \cdot \mathrm{n}_{\mathrm{b}}$ & $\lambda\left(2 \mathrm{y}_{\mathrm{b}_{1}} \cdot \mathrm{n}_{\mathrm{b}}\right)$ & $\mathrm{y}_{\mathrm{b}_{2}} \cdot \mathrm{n}_{\mathrm{b}}$ & - & $\frac{\mathrm{y}_{\mathrm{u}_{2}}}{\mathrm{y}_{\mathrm{b}_{1}} \cdot \mathrm{n}_{\mathrm{b}}}\left\{\lambda\left(2 \mathrm{y}_{\mathrm{b}_{1}} \cdot \mathrm{n}_{\mathrm{b}}\right)\right\}$ \\
\hline Product & - & $2 \mathrm{y}_{\mathrm{b}_{1}} \cdot \mathrm{n}_{\mathrm{b}}$ & $\mathrm{y}_{\mathrm{b}_{1}} \cdot \mathrm{n}_{\mathrm{b}}$ & $2 \mathrm{y}_{\mathrm{b}_{1}} \cdot \mathrm{n}_{\mathrm{b}}$ & - \\
\hline
\end{tabular}

Fig 2. Calculation scheme of input and output gases

The scheme of combustion process in combustion chamber is presented in Fig. 1.

$\mathrm{CH}_{4}$ and $\mathrm{CO}_{2}$ are the main component that present in biogas [7,32], other components like $\mathrm{H}_{2} \mathrm{~S}, \mathrm{H}_{2} \mathrm{O}$, and $\mathrm{NH}_{3}$ exist in relative small amount [33], therefore, in this simulation, it is assumed that biogas only contain of $\mathrm{CH}_{4}$ and $\mathrm{CO}_{2}$. The methane content in biogas is expressed by $\mathrm{C}_{\mathrm{b}_{1}}$ (\% volume), $\mathrm{CO}_{2}$ content in biogas is expressed by $\mathrm{C}_{\mathrm{b}_{2}}$ (\% volume), mole fraction of methane in biogas expressed by $\mathrm{y}_{b_{1}}$, and mole fraction of $\mathrm{CO}_{2}$ in biogas is expressed by $y_{b_{2}}$. The value of $y_{b_{1}}$ and $y_{b_{2}}$ can be calculated using eq. 1 and 2 as follow:

$\mathrm{y}_{\mathrm{b}_{1}}=\left(\frac{\mathrm{C}_{\mathrm{b}_{1}}}{\mathrm{C}_{\mathrm{b}_{1}}+\mathrm{C}_{\mathrm{b}_{2}}}\right)$

$\mathrm{y}_{\mathrm{b}_{2}}=\left(\frac{\mathrm{C}_{\mathrm{b}_{2}}}{\mathrm{C}_{\mathrm{b}_{1}}+\mathrm{C}_{\mathrm{b}_{2}}}\right)$

To oxidize $\mathrm{CH}_{4}$ in biogas, it is used atmospheric air that assumed contain of $\mathrm{O}_{2}$ as much as $20 \%$ and $\mathrm{N}_{2}$ as much as $80 \%$. Mole fraction of oxygen in the air is expressed by $\mathrm{y}_{\mathrm{u}_{1}}$ and mole fraction of nitrogen in the air is expressed by $\mathrm{y}_{\mathrm{u}_{2}}$. The combustion reaction is happen in the combustion chamber between $\mathrm{CH}_{4}$ in the biogas and $\mathrm{O}_{2}$ from the air:

$\mathrm{CH}_{4}+2 \mathrm{O}_{2} \rightarrow \mathrm{CO}_{2}+2 \mathrm{H}_{2} \mathrm{O}$

The combustion product gases consist of $\mathrm{CO}_{2}$ and $\mathrm{H}_{2} \mathrm{O}$ produced from the reaction and other gases that not involved in the combustion reaction i.e. $\mathrm{CO}_{2}$ from input biogas to combustion chamber, $\mathrm{N}_{2}$ inert and excess $\mathrm{O}_{2}$ from input air to combustion chamber. Mole fraction of
$\mathrm{CH}_{4}, \mathrm{O}_{2}, \mathrm{CO}_{2}, \mathrm{H}_{2} \mathrm{O}$, and $\mathrm{N}_{2}$ in the combustion gases are then expressed by $\mathrm{y}_{1}, \mathrm{y}_{2}, \mathrm{y}_{3}, \mathrm{y}_{4}$, and $\mathrm{y}_{5}$ respectively. For the combustion of $\mathrm{V}_{\mathrm{b}} \mathrm{m}^{3}$ biogas, the moles amount of this biogas can be calculated using ideal gas equation, as follow:

$n_{b}=\frac{P V_{b}}{R T_{i}}$

in which $n_{b}$ is moles of biogas $(\mathrm{gmol}), P$ is pressure (atm), R is ideal gas constant (L.atm/gmol.K), and $T_{i}$ is temperature of input gases to combustion chamber (K). In order to reach complete combustion, it is needed to design input oxygen higher than stoichiometric need. The air biogas equivalence ratio is defined as the ratio of actual air biogas ratio to the stoichiometric air biogas ratio. If the air biogas equivalence ratio is $\lambda$, the amount of input air and products of the combustion reaction can be estimated based on the stoichiometric reaction of biogas combustion as presented in the scheme in Fig. 2.

Amount of $\mathrm{CH}_{4}, \mathrm{O}_{2}, \mathrm{CO}_{2}, \mathrm{H}_{2} \mathrm{O}$ and $\mathrm{N}_{2}$ in the input gases can be calculated using eq. $5,6,7,8$, and 9 , as follow:

$\mathrm{n}_{\mathrm{i}_{1}}=\mathrm{y}_{\mathrm{b}_{1}} \cdot \mathrm{n}_{\mathrm{b}}$

$\mathrm{n}_{\mathrm{i}_{2}}=\lambda\left(2 \mathrm{y}_{\mathrm{b}_{1}}, \mathrm{n}_{\mathrm{b}}\right)$

$\mathrm{n}_{\mathrm{i}_{3}}=\mathrm{y}_{\mathrm{b}_{2}} \cdot \mathrm{n}_{\mathrm{b}}$

$\mathrm{n}_{\mathrm{i}_{4}}=0$

$n_{i_{5}}=\frac{y_{u_{2}}}{y_{u_{1}}}\left\{\lambda\left(2 y_{b_{1}} \cdot n_{b}\right)\right\}$

with $n_{i_{1}}, n_{i_{2}}, n_{i_{3}}, n_{i_{4}}$, and $n_{i_{5}}$ respectively is moles of $\mathrm{CH}_{4}, \mathrm{O}_{2}, \mathrm{CO}_{2}, \mathrm{H}_{2} \mathrm{O}$, and $\mathrm{N}_{2}$ in the input gases stream (gmol). It is assumed that no $\mathrm{H}_{2} \mathrm{O}$ presence in the biogas 


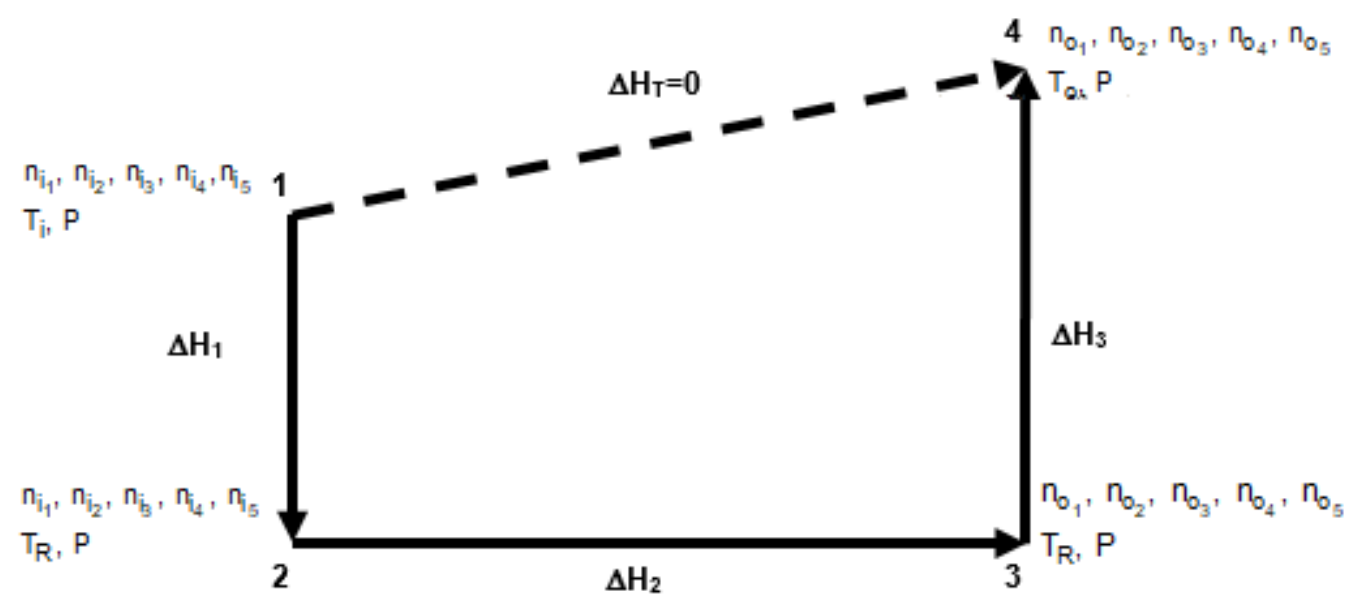

Fig 3. The enthalpy change in biogas combustion process

and combustion air, so that the value of $n_{i_{4}}$ is zero. Total moles of input gases into combustion chamber $\left(n_{i_{t}}\right.$, gmol) can be calculated by summing moles of each component. Because biogas only consist of $\mathrm{CH}_{4}$ and $\mathrm{CO}_{2}$, the value of $\mathrm{y}_{b_{1}}+\mathrm{y}_{b_{2}}=1$. Total amount of input gases can be calculated as follow:

$\mathrm{n}_{\mathrm{i}_{\mathrm{t}}}=\mathrm{n}_{\mathrm{b}}+\lambda\left(2 \mathrm{y}_{\mathrm{b}_{1}} \cdot \mathrm{n}_{\mathrm{b}}\right)+\frac{\mathrm{y}_{\mathrm{u}_{2}}}{\mathrm{y}_{\mathrm{u}_{1}}}\left\{\lambda\left(2 \mathrm{y}_{\mathrm{b}_{1}} \cdot \mathrm{n}_{\mathrm{b}}\right)\right\}$

with $n_{i_{t}}$ is total moles of input gases into combustion chamber (gmol).

Based on the scheme in Fig. 2, moles of $\mathrm{CH}_{4}, \mathrm{O}_{2}$, $\mathrm{CO}_{2}, \mathrm{H}_{2} \mathrm{O}$ and $\mathrm{N}_{2}$ in the combustion product gases can be calculated as follow:

$\mathrm{n}_{\mathrm{o}_{1}}=0$

$\mathrm{n}_{\mathrm{o}_{2}}=(\lambda-1)\left(2 \mathrm{y}_{\mathrm{b}_{1}} \cdot \mathrm{n}_{\mathrm{b}}\right)$

$\mathrm{n}_{\mathrm{O}_{3}}=\mathrm{n}_{\mathrm{b}}$

$\mathrm{n}_{\mathrm{o}_{4}}=2 \mathrm{y}_{\mathrm{b}_{1}} \cdot \mathrm{n}_{\mathrm{b}}$

$\mathrm{n}_{\mathrm{O}_{5}}=\frac{\mathrm{y}_{\mathrm{u}_{2}}}{\mathrm{y}_{\mathrm{u}_{1}}}\left\{\lambda\left(2 \mathrm{y}_{\mathrm{b}_{1}} \cdot \mathrm{n}_{\mathrm{b}}\right)\right\}$

with $\mathrm{n}_{\mathrm{O}_{1}}, \mathrm{n}_{\mathrm{O}_{2}}, \mathrm{n}_{\mathrm{O}_{3}}, \mathrm{n}_{\mathrm{O}_{4}}$, and $\mathrm{n}_{\mathrm{O}_{5}}$ respectively is moles of $\mathrm{CH}_{4}, \mathrm{O}_{2}, \mathrm{CO}_{2}, \mathrm{H}_{2} \mathrm{O}$, and $\mathrm{N}_{2}$ in the combustion product gases (gmol). Total moles of output gases from combustion chamber is the summation of moles of each component in the combustion product gases, be calculated as follow:

$\mathrm{n}_{\mathrm{o}_{\mathrm{t}}}=\mathrm{n}_{\mathrm{b}}+\lambda\left(2 \mathrm{y}_{\mathrm{b}_{1}} \cdot \mathrm{n}_{\mathrm{b}}\right)+\frac{\mathrm{y}_{\mathrm{u}_{2}}}{\mathrm{y}_{\mathrm{u}_{1}}}\left\{\lambda\left(2 \mathrm{y}_{\mathrm{b}_{1}} \cdot \mathrm{n}_{\mathrm{b}}\right)\right\}$

with $\mathrm{n}_{\mathrm{o}_{\mathrm{t}}}$ is total combustion gases (gmol).

Calculation of maximum temperature in this research was done based on common method to calculate combustion product temperature that also explained by [34-35]. The actual combustion process goes from the initial condition when the biogas and air enter to combustion chamber at temperature $\mathrm{T}_{\mathrm{i}}(\mathrm{K})$ to products at temperature $T_{0}(K)$ [34]. However, to ease the calculation, the maximum temperature of combustion gases was calculated based on the alternative process path in Fig. 3, from reactants at temperature $\mathrm{T}_{\mathrm{i}}(\mathrm{K})$ that are initially cooled to standard temperature $\left(T_{R}\right)$ of $298 \mathrm{~K}$, the combustion reaction is then carried out at a constant temperature of $298 \mathrm{~K}$, the product of combustion are then heated from $298 \mathrm{~K}$ to the final temperature of $T_{0}(K)$ [34]. The kinetic and potential energy changes are negligible and no work is done, so that the overall energy balance reduces to $\Delta \mathrm{H}_{\mathrm{T}}=0$ [35].

$\Delta \mathrm{H}_{1}$ (Joule) is the enthalpy change of reactants as they are cooled from $T_{i}$ to $T_{R}$, can be written as:

$\Delta \mathrm{H}_{1}=\int_{\mathrm{T}_{\mathrm{i}}}^{\mathrm{T}_{\mathrm{R}}}\left(\mathrm{n}_{\mathrm{i}_{1}} \cdot \mathrm{C}_{\mathrm{p}_{1}}+\mathrm{n}_{\mathrm{i}_{2}} \cdot \mathrm{C}_{\mathrm{p}_{2}}+\mathrm{n}_{\mathrm{i}_{3}} \cdot \mathrm{C}_{\mathrm{p}_{3}}+\mathrm{n}_{\mathrm{i}_{4}} \cdot \mathrm{C}_{\mathrm{p}_{4}}+\mathrm{n}_{\mathrm{i}_{5}} \cdot \mathrm{C}_{\mathrm{p}_{5}}\right) \cdot \partial \mathrm{T}$

with $C_{p_{1}}, C_{p_{2}}, C_{p_{3}}, C_{p_{4}}$, and $C_{p_{5}}$ respectively is heat capacity of $\mathrm{CH}_{4}, \mathrm{O}_{2}, \mathrm{CO}_{2}, \mathrm{H}_{2} \mathrm{O}$, and $\mathrm{N}_{2}$ (J/gmol.K).

$\Delta \mathrm{H}_{2}$ (Joule) is heat released from the combustion of methane in biogas, can be calculated as follow:

$\Delta \mathrm{H}_{2}=\mathrm{n}_{\mathrm{i}_{1}} \cdot \Delta \mathrm{H}_{\mathrm{c}}$

with $\Delta \mathrm{H}_{\mathrm{c}}$ is the standard heat of combustion of methane $(802620 \mathrm{~J} / \mathrm{gmol}$ in temperature of $298,15 \mathrm{~K}$ [36]).

$\Delta \mathrm{H}_{3}$ (Joule) is the enthalpy change of products as they are heated from $T_{R}$ to $T_{0}$, can be calculated as follow:

$\Delta \mathrm{H}_{3}=\int_{\mathrm{T}_{\mathrm{R}}}^{\mathrm{T}_{\mathrm{o}}}\left(\mathrm{n}_{\mathrm{O}_{1}} \cdot \mathrm{C}_{\mathrm{p}_{1}}+\mathrm{n}_{\mathrm{O}_{2}} \cdot \mathrm{C}_{\mathrm{p}_{2}}+\mathrm{n}_{\mathrm{O}_{3}} \cdot \mathrm{C}_{\mathrm{p}_{3}}+\mathrm{n}_{\mathrm{O}_{4}} \cdot \mathrm{C}_{\mathrm{p}_{4}}+\mathrm{n}_{\mathrm{O}_{5}} \cdot \mathrm{C}_{\mathrm{p}_{5}}\right) \cdot \partial \mathrm{T}$

$\Delta \mathrm{H}_{\mathrm{T}}$ (Joule) as the actual enthalpy change of the combustion process is the summation of $\Delta \mathrm{H}_{1}, \Delta \mathrm{H}_{2}$, and $\Delta H_{3}$. The maximum temperature will be achieved when no heat loss from the system and all of combustion 
heat is used to increase temperature of product gases, therefore with assumption that the system is adiabatic, the value of $\Delta \mathrm{H}_{\mathrm{T}}=0$, can be written as follow:

$\Delta \mathrm{H}_{\mathrm{T}}=\Delta \mathrm{H}_{1}+\Delta \mathrm{H}_{2}+\Delta \mathrm{H}_{3}=0$

The maximum temperature of the combustion product gases $\left(\mathrm{T}_{0}\right.$ ) can be calculated by substituting the value of $\Delta \mathrm{H}_{1}, \Delta \mathrm{H}_{2}$, and $\Delta \mathrm{H}_{3}$ in eq. 20 with the value of $\Delta \mathrm{H}_{1}, \Delta \mathrm{H}_{2}$, and $\Delta \mathrm{H}_{3}$ from eq. 17,18 , and 19 , and trying the value of $T_{0}$ until it is obtained the summation of $\Delta \mathrm{H}_{1}$, $\Delta \mathrm{H}_{2}$, and $\Delta \mathrm{H}_{3}$ in eq. 20 approximately to zero.

\section{RESULT AND DISCUSSION}

The calculation of combustion product and maximum temperature of biogas combustion were done based on the amount of input biogas to combustion chamber as much as $\mathrm{V} \mathrm{\textrm {m } ^ { 3 }}$, the temperature of input biogas and air into combustion chamber were assumed about $30{ }^{\circ} \mathrm{C}$, as the common ambient temperature in Indonesia. The combustion was carried out at constant pressure of $1 \mathrm{~atm}$. The data of $\mathrm{Cp}$ for each component that present in the combustion chamber were obtained from Smith et al. [35]. Based on the design variables mentioned above, the maximum temperatures of
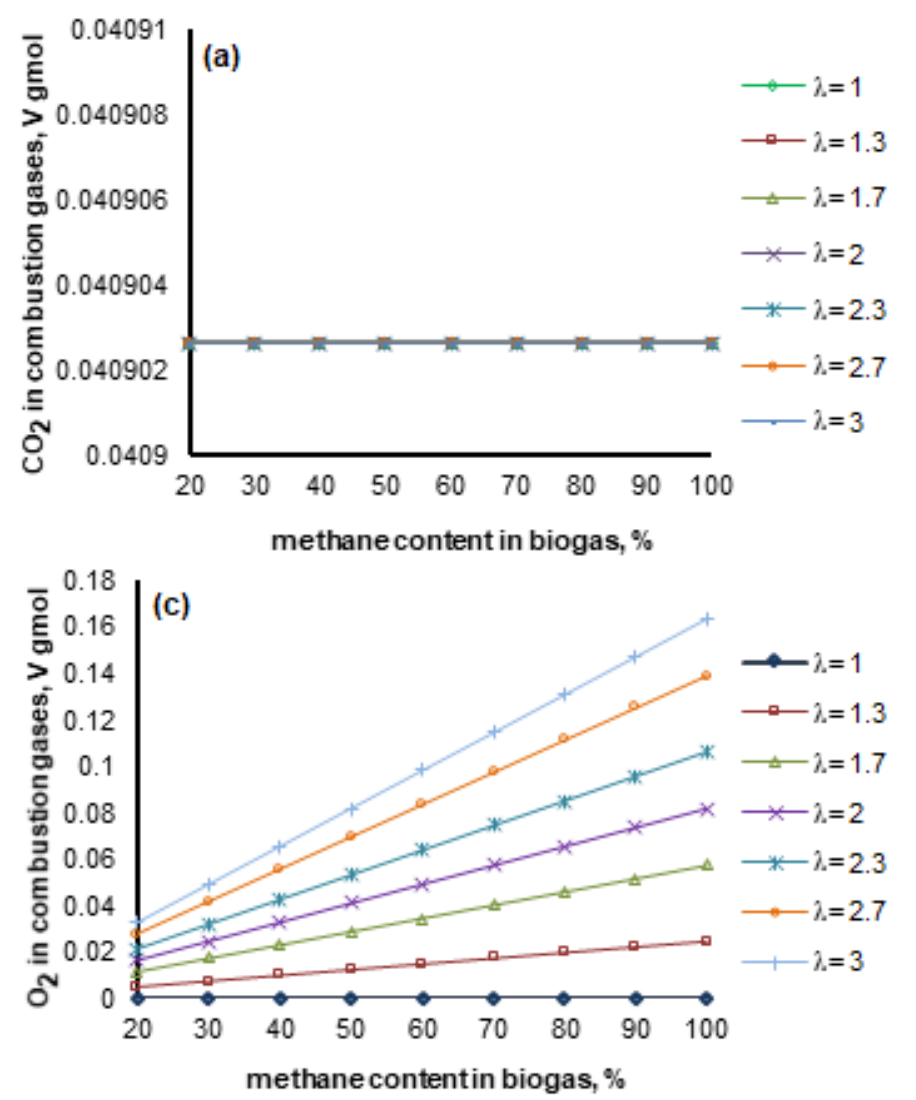

Fig 4. Composition of biogas combustion product (a) $\mathrm{CO}_{2}$, (b) $\mathrm{H}_{2} \mathrm{O}$, (c) $\mathrm{O}_{2}$, and (d) $\mathrm{N}_{2}$ combustion product gases were calculated by solve eq. 1-20 simultaneously. The simulation was done in the possibly range of methane content for biogas from 20 to $100 \%$ and air biogas equivalence ratio from 1 to 3 .

\section{Product Gases Composition}

The composition of combustion product gases is influenced by the composition of input gases and the combustion reaction that occur between methane in biogas and $\mathrm{O}_{2}$ from combustion air. Furthermore, the composition of input gases is influenced by the present of inert component and the excess of air in the combustion chamber or influenced by the methane content of biogas and air biogas equivalence ratio. Figure 4 show the calculation result of product gases from biogas combustion based on eq. 1-15.

Fig. $4 \mathrm{a}$ show that moles of $\mathrm{CO}_{2}$ in the combustion product gases show the same values in various level of methane and air biogas equivalence ratio. It happen because $\mathrm{CO}_{2}$ in the input gases is derived only from biogas and not from combustion air, therefore, component $\mathrm{CO}_{2}$ in the product gases is derived from $\mathrm{CO}_{2}$ in the input biogas and $\mathrm{CO}_{2}$ produced from combustion reaction of methane in biogas.
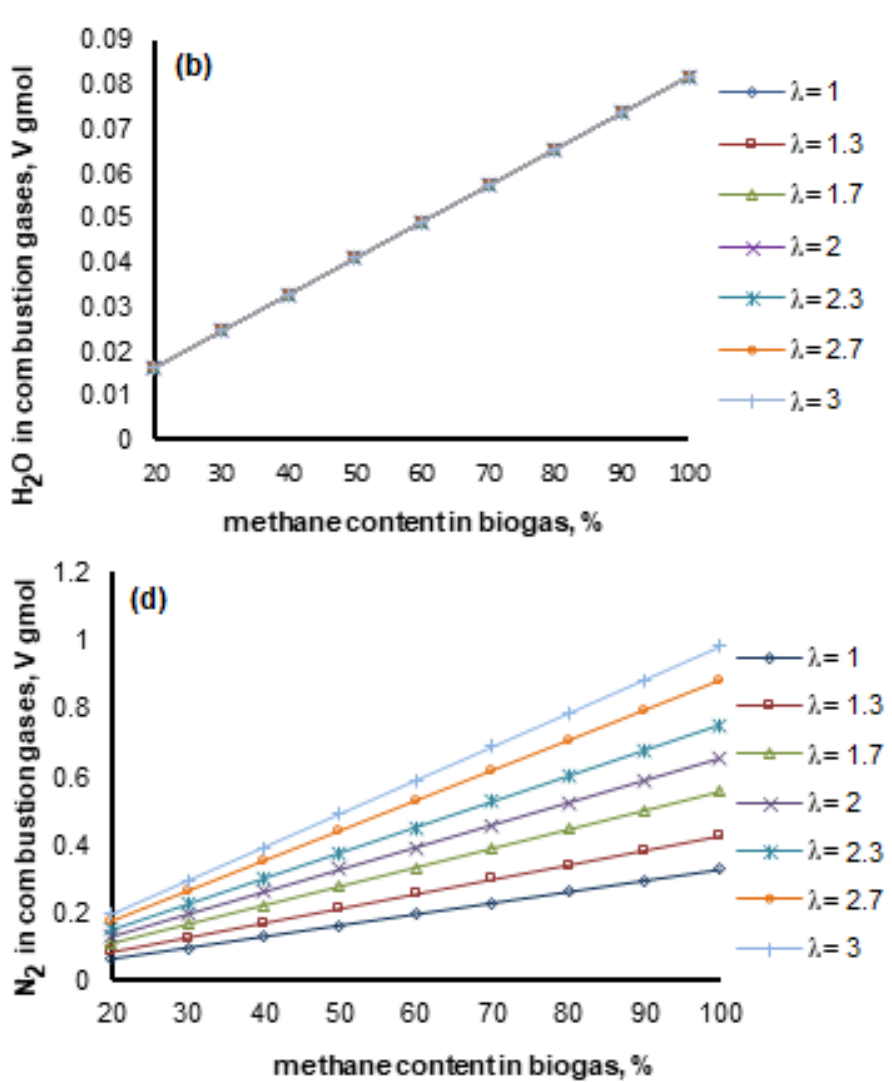
Since the reaction was assumed as complete combustion in all air biogas equivalence ratio, all of methane in biogas will be combusted to produce $\mathrm{CO}_{2}$ and $\mathrm{H}_{2} \mathrm{O}$. From eq. 3 it can be seen that the combustion reaction of methane will produce $\mathrm{CO}_{2}$ with same moles with $\mathrm{CH}_{4}$ involved in the reaction, therefore, because in the calculation it was assumed that biogas only consist of $\mathrm{CH}_{4}$ and $\mathrm{CO}_{2}$, moles $\mathrm{CO}_{2}$ in the combustion product gases as the summation of moles $\mathrm{CO}_{2}$ from input biogas and moles $\mathrm{CO}_{2}$ produced from the combustion reaction will be same with the total moles of $\mathrm{CO}_{2}$ and $\mathrm{CH}_{4}$ in the input biogas and also same with total moles of input biogas to combustion chamber. Due all the calculation was done based on $\mathrm{V} \mathrm{\textrm {m } ^ { 3 }}$ biogas $(0.0409 \mathrm{~V}$ gmol), moles of $\mathrm{CO}_{2}$ in the product gases will also $0.0409 \mathrm{~V} \mathrm{gmol} \mathrm{in}$ various methane content and air biogas equivalence ratio.

Fig. $4 \mathrm{~b}$ show that moles of $\mathrm{H}_{2} \mathrm{O}$ in the product gases in various air biogas equivalent ratio is same when the combusted biogas have same methane content. It happen because $\mathrm{H}_{2} \mathrm{O}$ was not existed in the input biogas and also not existed in the input air and only produced from the combustion reaction of methane in biogas, therefore the amount of $\mathrm{H}_{2} \mathrm{O}$ in the combustion product gases will depend on the amount of methane in biogas. When the methane content of biogas is same, although the air biogas equivalent ratio is different, based on the same volume of biogas to be combusted, the product $\mathrm{H}_{2} \mathrm{O}$ from complete combustion will also be same.

In the higher methane content, the amount of methane to be combusted is higher so that the amount of $\mathrm{H}_{2} \mathrm{O}$ produced from the reaction will also be higher, that imply in the higher amount of $\mathrm{H}_{2} \mathrm{O}$ in the combustion product gases. $\mathrm{H}_{2} \mathrm{O}$ present in the combustion product gases from about $0.01636 \mathrm{~V}$ gmol when the methane content $20 \%$ up to about $0.08181 \mathrm{~V} \mathrm{gmol}$ when the methane content of biogas is $100 \%$ (pure methane).

Fig. $4 \mathrm{c}$ and $4 \mathrm{~d}$ show that moles of $\mathrm{O}_{2}$ and $\mathrm{N}_{2}$ in the combustion gases tend to increase with the increasing of air biogas equivalence ratio and also with the increasing of methane content in biogas. Because $\mathrm{O}_{2}$ and $\mathrm{N}_{2}$ were the main component in the combustion air, when the air biogas equivalence ratio is higher and the methane content is same, the amount of input air into combustion chamber will be higher that mean the higher input $\mathrm{O}_{2}$ and $\mathrm{N}_{2}$. In the same methane content, the amount of $\mathrm{O}_{2}$ reacted will be same, when the air input is higher, the excess $\mathrm{O}_{2}$ that involved in the combustion gases will also be higher (Fig. 4c). For $\mathrm{N}_{2}$, the higher air biogas equivalence ratio means the higher input air and also the higher input $\mathrm{N}_{2}$. Because $\mathrm{N}_{2}$ is an inert component, the higher $\mathrm{N}_{2}$ in the input air will imply in the higher $\mathrm{N}_{2}$ in the combustion product gases (Fig. 4d).
In the same air biogas equivalence ratio, the amount of $\mathrm{O}_{2}$ and $\mathrm{N}_{2}$ in the combustion gases is tends to increase with the increasing of methane content in biogas. When the methane content is higher, the amount of methane in biogas is higher too, it imply in the higher input air to be fed in to combustion chamber, as well as $\mathrm{O}_{2}$ and $\mathrm{N}_{2}$. Furthermore, the amount of $\mathrm{N}_{2}$ in the combustion gases as inert component in the combustion process will also be higher (Fig. $4 d$ ). $\mathrm{N}_{2}$ in the combustion gases calculated as much as $0.06544 \mathrm{~V}$ gmol in methane content $20 \%$ and air biogas equivalence ratio 1 , and, $0.98166 \mathrm{~V}$ gmol when the methane content $100 \%$ and air biogas equivalence ratio 3.

For $\mathrm{O}_{2}$, although some $\mathrm{O}_{2}$ in combustion air will involve in the combustion reaction, when the methane content is higher, the excess $\mathrm{O}_{2}$ in certain air biogas equivalence ratio will also be higher (Fig. 4c). The amount of $\mathrm{O}_{2}$ that involved in the combustion reaction will be equivalence with methane content of biogas, and, in the same air biogas equivalence ratio, the excess $\mathrm{O}_{2}$ will also be equivalence with the methane content of biogas. There were no excess $\mathrm{O}_{2}$ in the combustion gases when the air biogas equivalence ratio is 1 because all input $\mathrm{O}_{2}$ from combustion air involved in the combustion reaction. Excess $\mathrm{O}_{2}$ can reach $0.03272 \mathrm{~V} \mathrm{gmol}$ when the air biogas equivalence ratio is 3 and the methane content is $100 \%$.

Totally, all of the calculation showed that the main component present in the biogas combustion product are $\mathrm{CO}_{2}, \mathrm{H}_{2} \mathrm{O}, \mathrm{O}_{2}$, and $\mathrm{N}_{2} . \mathrm{N}_{2}$ as an inert component, present in high amount, more than $50 \%$. Fig. 4 show that $\mathrm{N}_{2}$ present in combustion gases from about $0.0654 \mathrm{~V} \mathrm{gmol}$ to about $0.98166 \mathrm{~V} \mathrm{gmol}$, significant higher than $\mathrm{CO}_{2}$ as much as $0.04090 \mathrm{~V}$ gmol, also significant higher than $\mathrm{H}_{2} \mathrm{O}$ from about $0.01636 \mathrm{~V}$ gmol to $0.08181 \mathrm{~V} \mathrm{gmol}$, and also than $\mathrm{O}_{2}$ from $0 \mathrm{gmol}$ to $0.03272 \mathrm{~V} \mathrm{gmol}$. In the actual combustion process, the combustion gases may also contain $\mathrm{CO}$ as a result of uncompleted combustion [26], some unburned methane, and $\mathrm{NO}_{x}$ as a result of $\mathrm{N}_{2}$ oxidation in high combustion temperature [26].

\section{Maximum Temperature of Product Gases}

The maximum temperature of combustion gases is influenced by the composition and temperature of input gases, combustion reaction temperature, composition of combustion product gases and the heating value of biogas. Fig. 5 shows the correlation of those parameters with methane content of biogas when the air biogas equivalence ratio was 1.3 (Fig. 5a) and with air biogas equivalence ratio when the methane content of biogas was $50 \%$ (Fig. 5 b). 

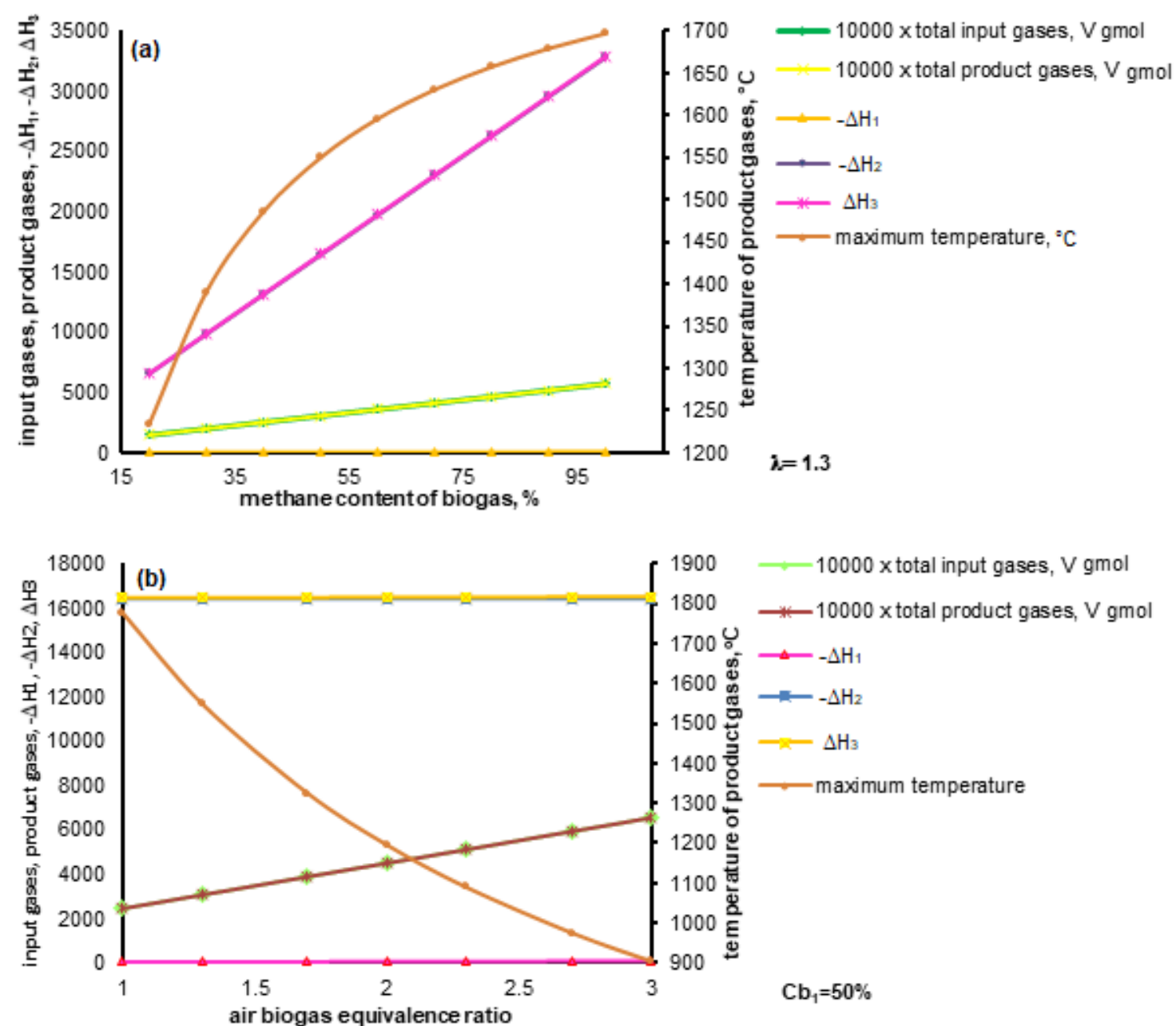

Fig 5. Total input gases, total product gases, $-\Delta \mathrm{H}_{1},-\Delta \mathrm{H}_{2}, \Delta \mathrm{H}_{3}$, and maximum temperature of combustion product (a) in various methane content of biogas, and (b) in various air biogas equivalence ratio

Based on the alternative process path in Fig. 3, the maximum temperature of product gases from biogas combustion is obtained from the sensible heat that was released from the input gases to reach the combustion reaction temperature and from the heat released from the combustion of methane in biogas (in actual process, the heat that was released from the combustion reaction directly increased the combustion gases temperature), however, because the differences between input gases temperature $\left(30{ }^{\circ} \mathrm{C}\right)$ and combustion reaction temperature $\left(25^{\circ} \mathrm{C}\right)$ was not significant, the phenomena that can be seen in Fig. $5 \mathrm{a}$ and $5 \mathrm{~b}$ show that almost all heat that be used to increase the temperature of combustion gases was derived from the heat of combustion of biogas, and very little heat derived from the sensible heat released from the reactant. This trend was showed by the position of line $-\Delta \mathrm{H}_{1},-\Delta \mathrm{H}_{2}$, and $\Delta \mathrm{H}_{3}$ in Fig. $5 a$ and $5 b$.

The position of line $-\Delta \mathrm{H}_{2}$ and $\Delta \mathrm{H}_{3}$ were almost coincident, the value of $\Delta \mathrm{H}_{3}$ slightly higher than the value of $-\Delta \mathrm{H}_{2}$, in the other hand the position of line $-\Delta \mathrm{H}_{1}$ was very low. The value of $-\Delta \mathrm{H}_{1}$ as much as $22.3737 \mathrm{~V}$ Joule in methane content $20 \%$ and air biogas equivalence ratio 1.3 and $94.0321 \mathrm{~V}$ Joule in methane content $50 \%$ and air biogas equivalence ratio 3 , were not significant compared with the value of $-\Delta \mathrm{H}_{2}$ as much as $6565.8553 \mathrm{~V}$ Joule in methane content $20 \%$ and air biogas equivalence ratio 1.3 and $16414.6382 \mathrm{~V}$ Joule in methane content $50 \%$ and air biogas equivalence ratio 3 . When the methane content was $100 \%$ and the air biogas equivalence ratio was 1.3 the value of $-\Delta \mathrm{H}_{2}$ is approximately of $32829.2765 \mathrm{~V}$ Joule. The value of $-\Delta \mathrm{H}_{2}$ just slightly lower than the value of $\Delta \mathrm{H}_{3}$ as much as $6588.2290 \mathrm{~V}$ Joule in methane content $20 \%$ and air biogas equivalence ratio 1.3 and 16508.6699V Joule in methane content $50 \%$ and air biogas equivalence ratio 3 .

Fig. 5a show that the maximum temperature of combustion product gases tend to increase with the increasing of methane content, as the effect of the 


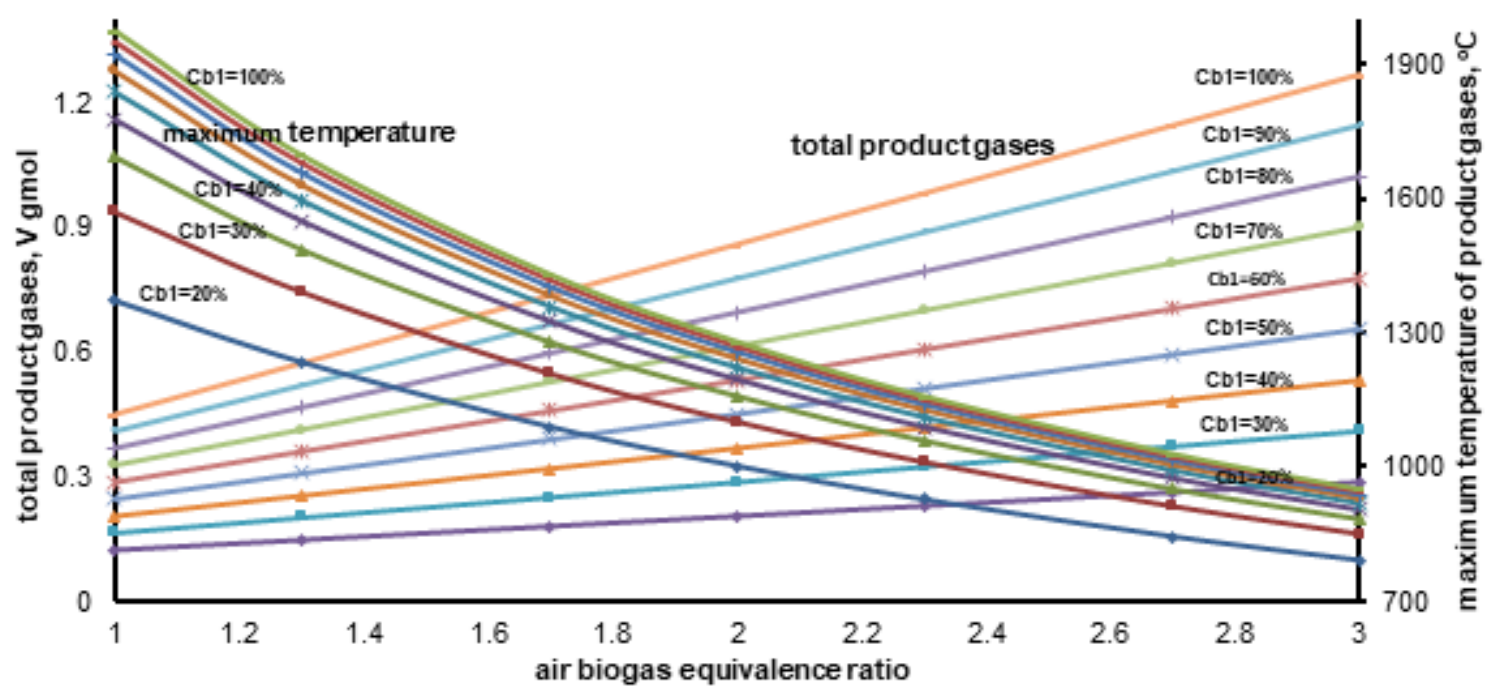

Fig 6. Total combustion gases and the maximum temperature

increasing of the heating value of biogas. In the other hand, although the value of the negative combustion enthalpy $\left(-\Delta H_{2}\right)$ is linearly increase with methane content however the increasing of maximum temperature of combustion gases tend to decrease with the increasing of methane content (can be seen from the line of temperature that not linier but it is curved with slope to be smaller by the increasing of methane content). There are a significant increase of amount of combustion product gases from the combustion of biogas with high level methane due to the increasing of the amount of feed air into combustion chamber that further more imply in the increasing of excess $\mathrm{O}_{2}$ and $\mathrm{N}_{2}$ inert in the combustion product gases. Those gases need sensible heat to reach same temperature with others component in combustion product, that further more decrease the increasing of maximum temperature reached. This analysis in accordance with Colorado research [37], in which the increased amount of inert gases cool down the reactions lowering the temperature of the chamber.

The influence of inert component and excess $\mathrm{O}_{2}$ from the combustion air on maximum temperature of product gases can be seen clearly in Fig. $5 \mathrm{~b}$. In the same methane content (same heating value of biogas), the increasing of air biogas equivalence ratio will effect in the significant increasing of the amount of combustion gases with excess $\mathrm{O}_{2}$ and $\mathrm{N}_{2}$ inert that furthermore decrease the maximum temperature. When the methane content is $50 \%$ and air biogas equivalence ratio is 1 , the maximum temperature reached is up to $1700{ }^{\circ} \mathrm{C}$, and significantly decrease to below $1195{ }^{\circ} \mathrm{C}$ when the air biogas equivalence ratio is 2 . The overall result about the product gases and the maximum temperature reached is presented in Fig. 6.

In accordance with the trend in Fig. 5b, Fig. 6 show that the maximum temperature of product gases tend to decrease with the increasing of air biogas equivalence ratio due to the present of a lot of inert component (excess $\mathrm{O}_{2}$ and $\mathrm{N}_{2}$ inert from combustion air) in the combustion product gases.

The trend in Fig. $5 \mathrm{a}$ also can be seen clearly in Fig. 6, the temperature of combustion gases was tend to increase with the increasing of methane content in biogas, showed by the position of temperature line in the chart that was higher in the higher methane content. The amount of combustion gases was from $0.12271 \mathrm{~V} \mathrm{gmol}$ in methane content $20 \%$ and air biogas equivalence ratio 1 to $1.26798 \mathrm{~V} \mathrm{gmol}$ when the methane content $100 \%$ and air biogas equivalence ratio 3 . The maximum temperature of combustion gases was approximately between $791.75382{ }^{\circ} \mathrm{C}$ in methane content $20 \%$ and air biogas equivalence ratio 3 and $1974.95080^{\circ} \mathrm{C}$ in methane content $100 \%$ and air biogas equivalence ratio 1 .

In the application of biogas system, the methane content of biogas will depend on the type of organic material used as substrate and the purification process carried out, and, the amount of input air need to be designed according to the value of lower and upper flammability limit so that the combustion reaction can well occur. According to Matheson [38], the flammable range of methane was $5-15 \%$. When the combustion air is limited or only in the amount of stoichiometric need, uncompleted combustion may occur and $\mathrm{CO}$ will present in the combustion gases, this $\mathrm{CO}$ still have calorific value that further more decrease the temperature reached. In the other hand the big amount of combustion air will also decrease the temperature of combustion gases, and too big amount of air will cause the concentration of methane in the input gases below the lower flammability limit so that the combustion reaction did not occur [39]. 
Table 1. Comparation with previous study

\begin{tabular}{lcl}
\hline Methane content, $\%$ & ${\text { Temperature from simulation, }{ }^{\circ} \mathbf{C}}$ & ${\text { Temperature from previous study, }{ }^{\circ} \mathbf{C}}^{\circ}$ \\
\hline 40 & $883-1692$ & $\sim 1427-1479[29]$ \\
51 & $906-1783$ & $600-1200[31]$ \\
60 & $919-1838$ & $877-957[28], \sim 1500[28] \sim 1427-1521[29], 1587[27], 907[37]$ \\
61 & $920-1843$ & $\sim 1427-1566[29]$ \\
65 & $924-1862$ & $1852[5]$ \\
100 & $950-1974$ & $1952[5], \sim 1427-1567[29]$ \\
$45-100$ & $894-1974$ & $1727-1952[5]$ \\
$20-100$ & 7911974 & $895-2085[26]$ \\
\hline
\end{tabular}

\section{Comparation with Previous Researches}

The result of the simulation in this research then compared with the result of previous researches, as can be seen in Table 1.

Information in Table 1 show that largely the value of combustion temperature from previous researches was in the range value of maximum temperature from the simulation. Slightly differences can be seen when the simulation results were compared with the numerical study done by Noor et al. [28], and experimental result done by Colorado et al. [37], in where the lowest temperature of the range of average temperature [28] and the average temperature [37] resulted from previous researches were slightly lower than the lowest temperature value obtained from the simulation. Since the temperatures from previous researches $[28,37]$ were the average temperatures, those temperatures will always be lower than the maximum temperatures. The presence of little unburned methane [28], little incomplete combustion that produce $\mathrm{CO}[28,37]$, and little NOx formation [37] will also decrease the temperature. Since this simulation was done in complete condition, the temperature obtained will be higher. The maximum temperature obtained by Noor et al. for air oxygen mole fraction $20 \%$ approximately of $1500{ }^{\circ} \mathrm{C}$ [28] was in the range of maximum temperature obtained in this simulation.

The values of temperature obtained by Dahiya et al. (for non-seeded combustion product) [5] also in the range of simulation result, however because the data of Dahiya et al. were obtained for stoichiometric condition, the value of the temperature were in the high value of the range of temperature from the simulation. Any lower temperatures from the simulation were obtained because the simulation was done in the excess of air and the higher temperature obtained because the simulation was done for complete combustion. Dahiya et al. research considered the dissociation reaction of the product and component gases in the combustion process that imply in the decreasing of temperature achieved.

The lowest temperature value obtained by Biogas Technology Limited [31] was lower approximately of 300 ${ }^{\circ} \mathrm{C}$ than the lowest temperature from the simulation. This differences could be caused by unburned methane (when the temperature fall below $1000{ }^{\circ} \mathrm{C}$, the lower temperature provides a documented destruction efficiency [31]), incomplete combustion, endothermic reaction in the formation of NOx, and the effect of wind at the stack [31]. CO and NOx were exist in the exhaust gases for all of the experiment conducted. When the temperature was $657^{\circ} \mathrm{C}, \mathrm{CO}$ in the exhaust gases amounted as $538.34 \mathrm{mg} / \mathrm{m}^{3}$ [31]. For temperature $875{ }^{\circ} \mathrm{C}, \mathrm{CO}$ in the exhaust gases amounted as $182.87 \mathrm{mg} / \mathrm{m}^{3}$ [31].

The temperature resulted from the simulation were approximately $103-110^{\circ} \mathrm{C}$ below the theoretical flame temperature presented by Caine [26]. The differences of the lowest temperature (the lowest value of the range of temperature) obtained could be caused by the higher air biogas equivalence ratio simulated in this research (up to 3 , the Caine research only conducted up to air biogas equivalence ratio about 2) that caused the lower temperature obtained from simulation. In the other hand the differences of the highest temperature (the highest value of the range temperature obtained) could not clearly be analyzed due to the limited information from Caine [26]. Since the highest temperature was obtained when the air biogas equivalence ratio amounted as 1 and methane content as $100 \%$ that was simulated in this research and presented in the previous research [26], those highest temperatures should be not significant different. It was predicted that the differences could be caused by the differences of the assumption used in the calculation or could be caused by the differences of initial temperature of input air and biogas.

\section{CONCLUSION}

The product composition and the maximum temperature that can be achieved from biogas combustion varies depend on the methane content of biogas and the designed air biogas equivalence ratio. From complete combustion, the product gases will be $\mathrm{CO}_{2}, \mathrm{H}_{2} \mathrm{O}$, excess $\mathrm{O}_{2}$, and inert $\mathrm{N}_{2}$. More than $50 \%$ component in the combustion gases was $\mathrm{N}_{2}$, an inert material that was carried along with the combustion air. For the combustion of $\mathrm{V} \mathrm{m}^{3}$ biogas, the total amount of 
product gases can reach $0.12271 \mathrm{~V}$ up to $1.26798 \mathrm{~V}$ gmol in the range methane content of $20-100 \%$ and air biogas equivalence ratio 1-3. The maximum temperature of product gases can reach more than $700{ }^{\circ} \mathrm{C}$ when the methane content is $20 \%$ and more than $1900{ }^{\circ} \mathrm{C}$ when the methane content can reach $100 \%$.

\section{ACKNOWLEDGEMENT}

The authors gratefully thank to Ghalya Pikra, M.T., Nur Rohmah, M.T., Arifin Santosa, S.T., and all researchers in Research Centre for Electrical Power and Mechatronics, Indonesian Institute of Sciences. The author would also thank to Ministry of Research, Technology, and Higher Education for funding support through,"Program Pendukung Beasiswa SAINTEK Kementerian Riset, Teknologi, dan Pendidikan Tinggi 2018".

\section{REFERENCES}

[1] Andriani, D., Wresta, A., Atmaja, T.D., and Saepudin, A., 2014, A review on optimization production and upgrading biogas through $\mathrm{CO}_{2}$ removal using various techniques, Appl. Biochem. Biotechnol., 172 (4), 1909-1928.

[2] Frost, P., and Gilkinson, S., 2010, Interim Technical Report. First 18 Month Performance Summary for Anaerobic Digestion of Dairy Cow Slurry at AFBI Hillsborough, Agrifood and Biosciences Institute, Hillsborough.

[3] Díaz-González, C., Arrieta, A.A., and Suárez, J. L., 2009, Comparison of combustion properties of simulated biogas and methane, CTF-Cienc. Tecnol. Futuro, 3 (5), 225-236.

[4] Mirzamohammad, N., Razbani, O., and Assadi, M., 2011, Review of theoretical and experimental studies implemented on (CHP) Micro turbine using natural gas and biogas fuels, Third International Conference on Applied Energy, Perugia, Italy, 16-18 May 2011.

[5] Dahiya, R.P., Chand, A., Sharma, S.C., and Dayal, M., 1986, Investigations of seeded combustion products of biogas/air- $\mathrm{O}_{2}$ systems, Energy Convers. Manage., 26 (2), 253-258.

[6] Ward, A.J., 2010, Biogas potential of fish wax (stearin) with cattle manure, Internal Report, Animal Scince, Department of Biosystems Engineering, Faculty of Agricultural Sciences, University of Aarhus, Aarhus.

[7] Dueblein, D., and Steinhauser, A., 2008, Biogas from Waste and Renewable Resources, KGaA: Wiley-VCH Verlag, Weinheim.

[8] Herringshaw, B., 2009, A Study of Biogas Utilization Efficiency Highlighting Internal Combustion
Electrical Generator Units, Undergraduate Honors Theses, The Ohio State University, Ohio.

[9] Wangyao, K., 2013, Landfill development and management (part 2): For LFGTE, ASEANSCSER (SCNCER) $2^{\text {nd }}$ Seminar Workshop: Capacity Building in Landfill Gas Utilization in ASEAN, Jakarta, 4 March 2013.

[10] Horikawa, M.S., Rossi, F., Gimenes, M.L., Costa, C.M.M., and da Silva, M.G.C., 2004, Chemical absorption of $\mathrm{H}_{2} \mathrm{~S}$ for biogas purification, Braz. J. Chem. Eng., 21 (3), 415-422.

[11] Karapidakis, E.S., Tsave, A.A., Soupios, P., and Katsigiannis, Y., 2010, Energy efficiency and environmental impact of biogas utilization in landfills, Int. J. Environ. Sci. Technol., 7 (3), 599608.

[12] Bari, S., 1996, Effect of carbon dioxide on the performance of biogas/diesel duel-fuel engine, Renewable Energy, 9 (1-4), 1007-1010.

[13] Bedoya, I.D., Saxena, S., Cadavid, F.J., Dibble, R.W., and Wissink, M., 2012, Experimental study of biogas combustion in an $\mathrm{HCCl}$ engine for power generation with high indicated efficiency and ultralow NOx emissions, Energy Convers. Manage., 53 (1), 154-162.

[14] Duc, P.M., and Wattanavichien, K., 2007, Study on biogas premixed charge diesel dual fuelled engine, Energy Convers. Manage., 48 (8), 2286-2308.

[15] Gaj, K., Knop, F., and Trzepierczyńska, I., 2009, Technological and environmental issues of biogas combustion at municipal sewage treatment plant, Environ. Prot. Eng., 35, 73-79.

[16] Henham, A., and Makkar, M., 1998, Combustion of simulated biogas in a dual-fuel diesel engine, Energy Convers. Manage., 39 (16-18), 20012009.

[17] Nathan, S.S., Mallikarjuna, J.M., and Ramesh, A., 2010, An experimental study of the biogas-diesel $\mathrm{HCCl}$ mode of engine operation, Energy Convers. Manage., 51 (7), 1347-1353.

[18] Porpatham, E., Ramesh, A., and Nagalingam, B., 2008, Investigation on the effect of concentration of methane in biogas when used as a fuel for a spark ignition engine, Fuel, 87 (8-9), 1651-1659.

[19] Porpatham, E., Ramesh, A., and Nagalingam, B., 2012, Effect of compression ratio on the performance and combustion of a biogas fuelled spark ignition engine, Fuel, 95, 247-256.

[20] Yoon, S.H., and Lee, C.S., 2011, Experimental investigation on the combustion and exhaust emission characteristics of biogas-biodiesel dualfuel combustion in a $\mathrm{Cl}$ engine, Fuel Process. Technol., 92 (5), 992-1000.

[21] Bohn, D., and Lepers, J., 2003, Effects of biogas combustion on the operation characteristics and 
pollutant emissions of a micro gas turbine, Proceedings of ASME Turbo Expo 2003, collocated with the 2003 International Joint Power Generation Conference, Atlanta, Georgia, USA, June 16-19, 2003, 247-257.

[22] Yang, C.H., Lee, C.C., and Chen, C.H., 2009, System identification and performance improvement to a micro gas turbine applying biogas, World Acad. Sci., Eng. Technol., 3 (10), 1172-1176.

[23] Bruno, J.C., Ortega-López, V., and Coronas, A., 2009 , Integration of absorption cooling systems into micro gas turbine trigeneration systems using biogas: case study of a sewage treatment plant, Appl. Energy, 86 (6), 837-847.

[24] Effuggi, A., Gelosa, D., Derudi, M., and Rota, R., 2008, Mild combustion of methane-derived fuel mixtures: natural gas and biogas, Combust. Sci. Technol., 180 (3), 481-493.

[25] Mandal, T., Kiran, B.A., and Mandal, N., 1999, Determination of the quality of biogas by flame temperature measurement, Energy Convers. Manage., 40 (11), 1225-1228.

[26] Caine, M., 2000, Biogas flares. State of the art and market review, Topic report of the IEA Bioenergy Agreement Task 24: Biological conversion of municipal solid waste, December, 11.

[27] Hosseini, S.E., Bagheri, G., Khaleghi, M., and Abdul Wahid, M., 2015, Combustion of biogas released from palm oil mill effluent and the effects of hydrogen enrichment on the characteristics of the biogas flame, J. Combust., 2015, 612341.

[28] Noor, M., Wandel, A.P., and Yusaf, T., 2013, Numerical study of oxygen dilution and temperature distribution of biogas combustion in Bluff-body MILD burner, Proceedings of the $7^{\text {th }}$ Australian Combustion Symposium (ACS 2013), University of Western Australia, Perth, 299-303.
[29] Hosseini, S.E., and Wahid, M.A., 2014, Development of biogas combustion in combined heat and power generation, Renewable and Sustainable Energy Rev., 40, 868-875.

[30] Lafay, Y., Taupin, B., Martins, G., Cabot, G., Renou, B., and Boukhalfa, A., 2007, Experimental study of biogas combustion using a gas turbine configuration, Exp. Fluids, 43 (2-3), 395-410.

[31] Biogas Technology Ltd., 2006, Procedure to determine the flare efficiency based on the flame temperature in an enclosed flare, Cambridgeshire.

[32] Tortora, G.J., Funke, B.R., and Case, C.L., 2010, Microbiology: An Introduction, 10 ${ }^{\text {th }}$ ed., Pearson Benjamin Cummings, San Francisco.

[33] Seadi, T.A., Rutz, D., Prassl, H., Köttner, M., Finsterwalder, T., Volk, S., and Janssen, R., 2008, Biogas Handbook, Seadi, T.A., Eds., University of Southern Denmark, Esbjerg.

[34] Smith, R.M., 2005, Chemical Process: Design and Integration, John Wiley \& Sons, New York.

[35] Smith, J.M., Ness, H.C.V., and Abbott, M.M., 2001, Introduction to Chemical Engineering Thermodynamics, McGraw-Hill Companies, Inc., New York.

[36] Green, D.W., and Perry, R.H., 2008, Perry's Chemical Engineers' Hand Book, $8^{\text {th }}$ ed., McGrawHill Companies, New York.

[37] Colorado, A., Herrera, B., and Amell, A., 2010, Performance of a flameless combustion furnace using biogas and natural gas, Bioresour. Technol., 101 (7), 2443-2449.

[38] Matheson Tri-Gas Inc., 2013, "Safety Data Sheet" in Material Name: Methane, Basking Ridge, New Jersey.

[39] Crowl, D.A., and Louvar, J.F., 2002, Chemical Process Safety: Fundamentals with Applications, $2^{\text {nd }}$ ed., Prentice Hall, Inc., New York. 